УДК 327.049.5(477)

ТКАЧУК А.П.

https://orcid.org/0000-0001-5594-2044

https://doi.org/10.33577/2313-5603.31.2019.69-80

\title{
БЕЗПЕКОВІ ЧИННИКИ ЗОВНІШНЬОЇ ПОЛІТИКИ УКРАЇНИ В УМОВАХ РОСІЙСЬКОЇ ВІЙСЬКОВОЇ АГРЕСІї
}

У даній науковій статті розглянуто концептуальні питання, що стосуються безпекових чинників у формуванні зовнішньої політики України. Окреслено чинники національної безпеки та їхнє місце у зовнішньополітичній діяльності України. Звернена увага на те, що в умовах російської агресії проти України питання національної безпеки залишається одним із ключових у формуванні іiі міжнародної політики. Показано, що через зовнішню політику Українська держава намагається долучитись до європейської системи безпеки, спираючись при цьому на власні сили і стратегічних партнерів. Зроблено висновки про те, що питання національної безпеки є важливою складовою при розбудові взаємин між Україною та іншими державами.

Ключові слова: міжнародні відносини, національна безпека, зовнішня політика, російська агресія.

Анексія Криму та розгортання Російською Федерацією військової агресії проти нашої держави, що призвело до фактичної окупації окремих районів Донецької та Луганської областей, внесли суттєві корективи в процес формування української державної політики у сфері національної безпеки та оборони. Не є винятком i зовнішньополітична діяльність нашої держави, адже, проводячи миролюбну зовнішню політику, Україна стала об’єктом агресії 3 боку держави, яка виступала гарантом їі територіальної цілісності та суверенітету згідно із Будапештськими меморандумом. Однак події першої половини 2014 р. змусили нашу державу кардинально переглянути підходи до визначення ключових засад зовнішньополітичної доктрини, яка в умовах військової агресії повинна була забезпечувати виконання завдань із збереження державного суверенітету та відновлення територіальної цілісності держави. Ефективне відстоювання національних інтересів на міжнародній арені ставало можливим лише в тому випадку, коли питання нацбезпеки та оборони були б враховані під час їі формування та реалізації.

Ткачук Андрій Павлович, кандидат історичних наук, аташе 3 питань оборони Посольства України у Республіці Австрія.

(C) Ткачук А.П., 2019 
У системі міжнародних відносин Україна продовжує залишатися стратегічно важливою державою в регіоні. Втім, як зазначав провідний український фахівець у галузі дослідження національної безпеки В. Горбулін, участь України у побудові нового світоустрою може бути активною і пасивною, а це, своєю чергою, може стати для неї або найважливішим критерієм розвитку державності, або, навпаки, іiі стагнації. У найближчій перспективі в нашої держави не залишається вибору, окрім як: або стати сильною державою, або зіштовхнутися $з$ реальною небезпекою поглинання (Горбулін, Власюк, Лібанова, Ляшенко, 2015). Саме тому дослідження зовнішньої політики України на предмет відстоювання національних інтересів, передусім у галузі зовнішньої політики, є як ніколи актуальним. Зазначимо, що у вітчизняній історіографії проблема національної безпеки у контексті здійснення Україною своєї зовнішньополітичної діяльності, окрім уже згадуваного В. Горбуліна, знайшла своє висвітлення в працях Г. Перепелиці, С. Віднянського, Л. Чекаленка, В. Почепцова, П. Гай-Нижника, А. Кудряченка, І. Тодорова та інших фахівців. Питання національної безпеки в зовнішній політиці в умовах анексії Криму та війни на Сході України, безсумнівно, є перспективними для фахових досліджень. Водночас не слід забувати, що такі дослідження потребують врахування усіх чинників, передусім - загрози розгортання повномасштабних бойових дій проти нашої держави з боку Росії. Адже будь-яка неточність у визначенні державних пріоритетів та неналежна оцінка наявних викликів ставить під загрозу подальше існування України як суверенної держави. Дослідження безпекових чинників у зовнішній політиці України в умовах російської агресії є метою даної статті.

Виклад основних результатів дослідження. Згідно із Основним законом нашої держави - Конституцією України - ключова роль у формуванні державної політики на міжнародній арені належить Президенту України. Також до іï практичної реалізації залучені український Уряд, вітчизняне МЗС, центральні органи виконавчої влади. Пріоритетом українських зовнішньополітичних зусиль у сфері забезпечення національної безпеки є входження України в європейський економічний і політичний простір, а також у систему колективної безпеки та інтеграції в НАТО. Сьогодні можна стверджувати про те, що у своїй більшості українське суспільство 3 розумінням ставиться до ролі держав Свропейського Союзу та членів Організації Північноатлантичного договору (НАТО) в побудові 
ефективної системи світової безпеки. В умовах нової конфігурації розстановки силових векторів у світі та в регіоні передусім відбувається поступова еволюція процесу творення системи колективної безпеки. Зростає розуміння важливості України з точки зору формування нової архітектури безпеки і в державах Заходу. Як приклад підтвердження важливості ролі України у сфері забезпечення безпеки, варто згадати слова представниці ЄС із зовнішніх справ та політики безпеки Ф. Могеріні, яка чітко вказала на залежність ефективності зовнішньої і безпекової політики Європейського Союзу від успішного вирішення конфлікту на Донбасі та втілення в життя необхідних реформ в Україні (Офіційний сайт Президента Украйни, 2015). Не залишається жодних сумнівів, що у процесі розвитку та будівництва європейської політики безпеки державні інтереси та цілі України є дотичними до інтересів та цілей країн СС.

Сучасна військово-політична ситуація навколо України вказує на те, що у воєнній сфері основні виклики та загрози національній безпеці нашої держави 3 боку Росії $є$ як ніколи актуальними. Зауважимо, що в окремі моменти суспільно-політичних подій в Україні вони стають динамічнішими, інтегруються з іншими викликами, які за своїм змістом не є військовими. Частина російських викликів щодо України носять асиметричний характер і поряд iз глобальними загрозами тероризму та кіберзлочинності значно переважають над «традиційними» військовими загрозами. Росія намагається переконати світову спільноту в своїй правоті, а тому використовує для цього всі наявні можливості. Як влучно зауважив український дослідник I. Тодоров, сила пропаганди, грошей та інших видів впливу призвела до того, що позиція Росії відстоюється не лише окремими прошарками населення, а й певними політичними силами і політиками (Тодоров, 2017:107).

В умовах військової загрози питання обороноздатності України та стану іiі армії стало потужним чинником у формуванні безпекової стратегії не лише України, але, наскільки видається, Свропейського континенту. В комплексі із дипломатичною та інформаційною діяльністю вони покликані відстоювати національні інтереси виключно мирним шляхом. Особливе значення у цьому випадку має дипломатія, адже завдяки вмілим, на наш погляд, діям вітчизняних дипломатів світове співтовариство дізналося про реальну ситуацію на Донбасі, підступну та реваншистську стратегію Кремля. Більше того, Україна отримала підтримку з боку громадськості провідних 
держав світу, що відбилося не лише у численних заявах та деклараціях, але й у санкційних списках проти РФ та в матеріальній і військовій допомозі Україні.

Окремі аспекти державної політики у сферах національної безпеки і оборони належать до комплексу питань, які традиційно отримують свою реалізацію через зовнішню політику. Зокрема, вони окреслені в Стратегії національної безпеки України, Стратегії воєнної безпеки України, Стратегії кібербезпеки України, документах, що стосуються держбезпеки та схвалені Радою національної безпеки i оборони України (РНБО), а також стали ключовою темою в щорічних посланнях Президента України до Парламенту (Сіиінський, 2017). На базовому рівні питання національної безпеки знайшли своє відображення в Законі «Про національну безпеку України» (Верховна Рада Украӥни, 2018), а також у Законі «Про особливості державної політики із забезпечення державного суверенітету України на тимчасово окупованих територіях у Донецькій та Луганській областях» (Верховна Рада України, 2018) та інших нормативноправових актах.

Починаючи з 2014 р., вище державне керівництво України намагалося сформувати державну політику в сфері безпеки згідно із ризиками, що склалися. Відповідні зміни втілились у низці законодавчих актів та нормативно-правових документів. Зокрема, Закон України «Про внесення змін до деяких законів України щодо відмови України від здійснення політики позаблоковості» постановив, що основним завданням України є iї інтеграція в європейський політичний, економічний, правовий простір. (Верховна Рада України, 2015).

Окремі аспекти національної безпеки, які реалізовуються державою під час іiі діяльності на міжнародній арені, закріплені у Стратегії сталого розвитку «Україна - 2020», яка була ухвалена Указом Президента України у січні 2015 р. У Стратегії визначено, що основними пріоритетами України є відновлення територіальної цілісності, створення ефективного сектору безпеки і оборони, підвищення обороноздатності держави, реформа ЗСУ, реформування державного управління, підвищення якості антикорупційної політики, інтеграція в СС та особливе партнерство з НАТО (Указ Президента Украӥни, 2015).

У «Стратегії національної безпеки України», затвердженій Указом Президента України 26 травня 2015 р., основними завданнями визначено мінімізацію загроз державному суверенітету, створення 
умов для відновлення територіальної цілісності України у межах міжнародно визнаного Державного кордону; гарантування іiі мирного майбутнього як суверенної і незалежної, демократичної, соціальної, правової держави; забезпечення інтеграції України у Європейський Союз та формування умов для вступу в НАТО (Сіиінський, 2017). Окрему увагу привертає положення, що стосується забезпечення національної безпеки на міжнародній арені. Відмовившись від політики позаблоковості, що не забезпечила територіальної цілісності держави, було зроблено акцент на тому, що в середньостроковій перспективі Україна повинна опиратися на власні можливості, а також зберігає за собою право обирати, в яких системах колективної безпеки і оборони ій брати участь задля забезпечення ефективного гарантування державного суверенітету і територіальної цілісності.

Геостратегічний вимір національної політики безпеки отримав висвітлення в Законі «Про внесення змін до деяких законів України щодо зовнішньополітичного курсу України» від 8 червня 2017 р. У ньому інтеграцію в НАТО визначено одним із національних пріоритетів. Як йшлося в документі, з цією метою Україна активізує зусилля з усього комплексу реформ, в тому числі у безпековому та оборонному секторах задля досягнення відповідності критеріям членства в Альянсі (Верховна Рада України, 2017).

3 огляду на високу ймовірність застосування воєнної сили проти нашої держави з боку Росії, іï було означено як однозначного противника у новій Воєнній доктрині України. В рішенні РНБО «Про нову редакцію Воєнної доктрини України» від 24 вересня 2015 р. було проаналізовано зміст та особливості відомих сучасних конфліктів, окреслено принципи і шляхи запобігання їх виникнення. Серед інших також розглядалися питання підготовки до воєнного конфлікту, захист суверенітету та територіальної цілісності за допомогою військових засобів. Цим документом наша держава підтвердила відмову від політики позаблоковості та у черговий раз задекларувала відновлення стратегічного курсу на євроатлантичну інтеграцію. Крім того, важливим моментом стало наголошення на потребі збільшення професійної складової у Збройних Силах України та в інших військових формуваннях, а також потребі удосконалення системи мобілізаційної підготовки і мобілізації. Загалом було сформовано комплекс заходів, необхідних для відновлення державного контролю над окупованими територіями, та визначено 
пріоритети з розвитку оборонної галузі України. Тобто було враховано усі складові безпекового потенціалу, які необхідні для протистояння агресору (Нова Воєнна доктрина Украӥни, 2015).

У Законі «Про національну безпеку України» зафіксовані базові положення та чітко унормовані існуючі виклики для України після анексії Криму та тимчасової окупації окремих територій Донецької і Луганської областей (Верховна Рада Украӥни, 2018). Положення правової основи державної політики у сферах національної безпеки і оборони закріплені в ст. 2. Водночас у наступній статті містяться принципи державної політики у сферах національної безпеки і оборони. До них належать:

- верховенство права, прозорість та дотримання засад демократичного цивільного контролю за функціонуванням сектору безпеки і оборони та застосуванням сили;

- єдине управління у сферах національної безпеки і оборони 3 метою забезпечення належного реагування на потреби Українського народу у сфері безпеки, ефективності виконання завдань, обов'язків та використання ресурсів;

- дотримання норм міжнародного права, участь в інтересах України у міжнародних зусиллях 3 підтримання миру і безпеки, міждержавних системах та механізмах міжнародної колективної безпеки;

- розвиток сектору безпеки і оборони як основного інструменту реалізації державної політики у сферах національної безпеки і оборони.

Фундаментальними національними інтересами України на зовнішньополітичній арені Законом визначено інтеграцію України в європейський політичний, економічний, безпековий та правовий простір, набуття членства в Свропейському Союзі та в Організації Північноатлантичного договору, розвиток рівноправних взаємовигідних відносин з іншими державами (Верховна Рада України, 2018). Звісно, це пов'язано з тим, що саме НАТО виступає головним чинником забезпечення безпеки в регіоні. Поряд із ними треба зважати на такі вектори безпекової політики на зовнішньополітичній арені, як ОБСЄ та Спільна європейська політика безпеки і оборони (СЄПБО) Європейського Союзу. Участь в Організації Договору про колективну безпеку (ОДКБ), на наш погляд, не слід розглядати, оскільки він не несе в собі жодних перспектив, а самі держави учасниці даного Договору проводять російськоцентричну зовнішню політику. 
ОБСЄ засвідчила свою ефективність у пошуку прийнятних для всіх сторін рішень з питань контролю над озброєннями, зміцнення довіри та регіональної безпеки. Крім цього, ефективність ОБСС в порівнянні 3 іншими організаціями держав Євроатлантичного та Євразійського регіонів полягала в тому, що організація усувала небезпеку ізоляції окремих країн, а також не мала жорстких обмежень свободи дій іiі членів. Звісно, в умовах військових дій на Донбасі та діяльності Спеціальної моніторингової місії (CMM) ОБСЄ на Донбасі виникають певні питання щодо іiї ефективності, адже організація зосередила свою діяльність виключно на аспектах верховенства права і прав людини, демократизації і належного державного управління, а також виконує функції форуму, на якому пострадянські країни мають можливість на рівних зустрічатися 3 європейськими країнами. Діяльність СММ є важливим внеском у процес мирного вирішення ситуації на Донбасі. Що стосується СЄПБО, то вона є складовою спільної зовнішньої політики та політики безпеки ЄС і має усі ознаки інституту колективної безпеки. Проте темпи формування самостійної оборонної складової ЄС, на наш погляд, залишаються повільними. Попри претензії ЄС на самостійну роль у формуванні безпеки і оборони, функції та спроможності ССПБО на сучасному етапі досить обмежені (попередження конфліктів і постконфліктна відбудова). Партнерство з СС у рамках діяльності цієї організації у світлі можливого набуття членства в СС можна б було вважати складовою державної політики євроатлантичної інтеграції. Поглиблення партнерства України з ЄС у рамках ССПБО є важливим напрямом міжнародних заходів iз забезпечення національної безпеки та вагомим внеском у регіональну і глобальну безпеку. Слід зазначити, що агресивна політика Росії та воєнні дії російської військової машини у різних «гарячих точках» світу спонукали європейське співтовариство до пошуку нової стратегії та тактики згідно з сучасними умовами. Як наслідок, різко зросли витрати на оборони у державах Прибалтики та Західних державах, що межують 3 нашою державою, - Польщі та Румунії. Через зовнішню політику Україна, спираючись на власні сили і стратегічних партнерів, намагається взяти участь у європейській системі безпеки. Сьогодні можна говорити про розбудову разом з країнами-сусідами своєрідної субрегіональної системи безпеки (як підтвердження можна вважати активізацію військових навчань спільної Литовсько-польсько-української бригади). 
Виклики російської агресії змусили Українську державу переглянути підхід до балансування між проросійським та західним векторами зовнішньої політики і чітко визначити пріоритетність євроатлантичного вектора у формуванні безпекової складової українського існування. Саме тому після численних дебатів i, подекуди, спроб політичних маніпуляцій, українським Парламентом (голосували «за» - 334 народних депутати із 385, зареєстрованих у сесійній залі) було підтримано президентський законопроект про внесення змін до Конституції України (щодо стратегічного курсу держави на набуття повноправного членства України в Свропейському Союзі та в Організації Північноатлантичного договору). Як зазначено в преамбулі Конституції, згідно з змінами Верховна Рада піклується про зміцнення громадянської злагоди на землі України та підтверджує європейську ідентичність Українського народу і незворотність європейського та євроатлантичного курсу країни. Статтею 85 за Верховною Радою України закріплено владу з визначення засад внутрішньої і зовнішньої політики, реалізації стратегічного курсу держави на набуття повноправного членства України в Європейському Союзі та НАТО. Натомість глава держави Президент України - виступає гарантом реалізації стратегічного курсу держави на набуття повноправного членства України в Свропейському Союзі та НАТО. Також Закон вказує на те, що Кабінет Міністрів забезпечує реалізацію стратегічного курсу держави на набуття повноправного членства України в Свросоюзі та НАТО (Верховна Рада України, 2019). Цілком імовірно, що у перспективі такий крок сприятиме формуванню нових стратегічних союзів держав, які формуватимуть систему регіональної і глобальної безпеки, а Україна в них зможе запропонувати власну ефективну альтернативу світовим викликам безпеки 3 урахуванням досвіду протистояння російській агресії.

Висновки. Питання національної безпеки у реалізації Україною своєї зовнішньої політики у сучасник умовах російської агресії $\epsilon$ надзвичайно вагомим й актуальним. Воно стосується таких сфер державної політики, як захист суверенітету та забезпечення міжнародної підтримки у протистоянні з агресором. Зовнішня політика України повинна враховувати особливості державної стратегії у сфері безпеки, як у внутрішньому (національно-державний), так i зовнішньому (регіональний і глобальний) вимірах. Опираючись на власні сили і стратегічних партнерів, Україна намагається взяти 
участь в європейській системі безпеки передусім через свою активну зовнішню політику. Подальше врахування безпекових аспектів під час формування і реалізації зовнішньої політики України дозволить розширити кількість потенційних союзників у побудові нової архітектури регіональної та глобальної безпеки, що в перспективі сприятиме підсиленню обороноздатності України.

\section{Використані посилання}

Верховна Рада України. 2015. Закон України Про внесення змін до деяких законів України щодо відмови України від здійснення політики позаблоковості. Закон від 23.12.2014 № 35-VIII. [online] Київ: ВРУ. Доступно: <http://zakon2.rada.gov.ua/laws/show/35-19> [Дата звернення 15 грудня 2018].

Верховна Рада України. 2017. Проект Закону про внесення змін до деяких законодавчих актів України (щодо зовнішньополітичного курсу України) [online] Київ: ВРУ. Доступно: <http://w1.c1.rada.gov.ua/pls/zweb2/webproc4_1?pf3511=61822> [Дата звернення 6 лютого 2019].

Верховна Рада України. 2018. Закон України Про національну безпеку України. [online] Київ: ВРУ. Доступно:

<https://zakon.rada.gov.ua/laws/show/2469-19> [Дата звернення 1 лютого 2019].

Верховна Рада України. 2018. Закон України Про особливості державної політики із забезпечення державного суверенітету України на тимчасово окупованих територіях у Донецькій та Луганській областях. [online] Київ: ВРУ. Доступно:

<http://zakon.rada.gov.ua/laws/show/2268-19> [Дата звернення 9 січня 2019].

Верховна Рада України. 2018. Проект Закону про внесення змін до Конституції України (щодо стратегічного курсу держави на набуття повноправного членства України в Європейському Союзі та в Організації Північноатлантичного договору) [online] Київ: ВРУ. Доступно: <http://w1.c1.rada.gov.ua/pls /zweb2/ webproc4_1?pf3511=64531> [Дата звернення 6 вересня 2018].

Власюк О.С., Кононенко С.В. 2017. Актуальні аспекти вдосконалення моделі національної безпеки України. Стратегічна панорама, Випуск № 1, с. 17-24. 
Горбулін В.П., Власюк О.С., Лібанова Е.М., Ляшенко О.М. 2015. Донбас і Крим: ціна повернення. Київ: НІСД, с. 474.

Інформаційно-аналітичний центр нацональної безпеки України. Нова Воєнна доктрина України. [online] Доступно:

$<$ http://mediarnbo.org/2015/09/04/nova-voyenna-doktrinaukrayini> [Дата звернення 17 січня 2019].

Сіцінський Н.А. 2017. Концептуальні принципи зовнішньополітичної діяльності України та іiі нормативно-правове наповнення. Інвестииії: практика та досвід, № 5, с. 97-104.

Тодоров І.Я. 2017. НАТО і війна на сході України (2014-2017рp.) Збірник наукових праць Стратегії зовнішньої та безпекової політики провідних міжнародних акторів. Київ: Державна установа «Інститут всесвітньої історії НАН України», с. 102-109.

Указ Президента України Про Стратегію сталого розвитку «Україна - 2020». 2015. [online] Київ: ВРУ. Доступно: <http://zakon2.rada.gov.ua/laws/show/5/2015> [Дата звернення 17 лютого 2019].

Україна залишається високим пріоритетом у зовнішній політиці Свропейського Союзу - зустріч Президента з Високим представником ЄС Могеріні. Офіщійний сайт Президента України [online] Доступно: <https://www.president.gov.ua/news/ukrayinazalishayetsya-visokim-prioritetom-u-zovnishnij-poli-36270> [Дата звернення 9 листопада 2018].

\section{REFERENCES}

Verkhovna Rada of Ukraine. 2015. The Law of Ukraine On Amendments to Some Laws of Ukraine Regarding Ukraine's Refusal to Implement Non-Subsidiarity Policy. Law dated December 23, 2014 № 35-VIII. [online] Kiev: VRU. Available at:

<http://zakon2.rada.gov.ua/laws/show/35-19> [Accessed 15 December 2018] (ukr).

Verkhovna Rada of Ukraine. 2017. Draft Law on Amendments to Certain Legislative Acts of Ukraine (regarding the foreign policy course of Ukraine) [online] Kyiv: VRU. Available at: <http://w1.c1 rada.gov.ua/pls/zweb2/webproc4_1?pf3511=61822> [Accessed 6 February 2019] (ukr). 
Verkhovna Rada of Ukraine. 2018. Law of Ukraine On National Security of Ukraine. [online] Kiev: VRU. Available at: <https://zakon.rada.gov.ua/laws/show/2469-19> [Accessed 1 February 2019] (ukr).

Verkhovna Rada of Ukraine. 2018. Law of Ukraine «On the peculiarities of state policy on ensuring the state sovereignty of Ukraine in temporarily occupied territories in the Donetsk and Luhansk oblasts.» [online] Kiev: VRU. Available at:

<http://zakon.rada.gov.ua/laws/show/2268-19> [Accessed 9 January 2019] (ukr).

Verkhovna Rada of Ukraine. 2018. Draft Law on Amendments to the Constitution of Ukraine (Regarding the Strategic Course of the State for Acquiring Full-fledged Membership of Ukraine in the European Union and the North Atlantic Treaty Organization) [online] Kiev: VRU. Available at:

<http://w1.c1rada.gov.ua/pls/zweb2/webproc4_1?pf3511=64531> [Accessed 6 September 2018] (ukr).

Vlasyuk O.S., Kononenko S.V. 2017. Current aspects of improving the national security model of Ukraine. Strategic Panorama, Issue \# 1, p. 17-24 (ukr).

Gorbulin V.P., Vlasyuk O.S., Libanova E. M., Lyashenko O.M. 2015. Donbass and Crimea: the price of return. Kyiv: NISS, p. 474 (ukr).

Information and Analytical Center of National Security of Ukraine. New Military Doctrine of Ukraine. [online] Available at: <http://mediarnbo.org/2015/09/04/nova-voyenna-doktrina-ukrayini> [Accessed 17 January 2019] (ukr).

Sitsinsky N.A. 2017. Conceptual Principles of Ukraine's Foreign Policy and its Regulatory Content. Investments: Practice and Experience, Issue 5, p. 97-104 (ukr).

Todorov I.Ya. 2017. NATO and the war in eastern Ukraine (20142017). Collection of scientific papers of the Strategy of foreign and security policy of leading international actors. Kyiv: State Institution «Institute of World History of the National Academy of Sciences of Ukraine», p. 102-109 (ukr).

Decree of the President of Ukraine on the Strategy for Sustainable Development «Ukraine - 2020». 2015. [online] Kiev: VRU. Available at: <http://zakon2.rada.gov.ua/laws/show/5/2015> [Accessed 17 February 2019] (ukr). 
Ukraine remains a high priority in foreign policy of the European Union - a meeting of the President with the High Representative of the EU Mogerini. The official website of the President of Ukraine [online] Available at: <https://www.president.gov.ua/news/ukrayinazalishayetsya-visokim-prioritetom-u-zovnishnij-poli-36270> [Accessed 9 November 2018] (ukr).

\section{Tkachuk A. \\ SECURITY FACTORS OF THE FOREIGN POLICY OF UKRAINE IN THE CONDITIONS OF RUSSIAN MILITARY AGGRESSION}

In this general paper, conceptual issues concerning security factors in the formation of Ukraine's foreign policy are devoted. The basic factors of national security and their place in foreign policy of Ukraine are outlined. The documentary sources show the growth of the security factor in the legislative acts adopted after 2014 in the cause of Russian aggression against Ukraine. It is indicated that effective defending of national interests on the international arena was only possible if national security and defense issues were taken into account when formulating and implementing foreign policy. It is shown that in the sphere of national security, the key priority of Ukrainian foreign policy efforts is Ukraine's entry into the European economic and political space, as well as the system of collective security and integration into NATO. Attention is drawn to the fact that in today's conditions of aggression against Ukraine, the question of national security remains one of the key issues in shaping the international policy of our state. Taking geopolitical challenges and harmonizing the foreign policy of the state with the principles of national security both in the internal and regional and global dimensions allows not only to ensure the proper functioning of foreign policy, but also to provide conditions for transformation, implementation of various measures for the entry into the complex of the new architecture of the regional and global security. It is concluded that national security issues are an important part of state policy in the international arena, as evidenced by numerous laws and regulations that directly or indirectly relate to Ukraine's foreign policy and its interaction with the world.

Keywords: international relations, national security, foreign policy, Russian aggression. 